\title{
Integration of Internet Technology to Support The Wayang Orang Ngesti Pandawa Business
}

\author{
Albertus Dwiyoga Widiantoro ${ }^{1, *}$, Ridwan Sanjaya ${ }^{2}$, Tjahyono Raharjo ${ }^{3}$ and A. Rachmat Djati Winarno ${ }^{4}$ \\ 1,2 Department of Information System, Faculty of Computer Science Soegijapranata Catholic University, Semarang - \\ Indonesia \\ ${ }^{3}$ Department of Environment and Urban Studies Soegijapranata Catholic University, Semarang - Indonesia \\ ${ }^{4}$ Fakulty of Psicology Soegijapranata Catholic University, Semarang - Indonesia
}

\begin{abstract}
Wayang orang is one of the cultural heritages that until now is still being preserved. However, the wayang orang Ngesti Pandawa in Semarang ifaces difficulty in attracting an audience. The number of viewers are few and limited to residents of Semarang and its surroundings. Internet technology, financial technology, website, social media integration, and government support is expected to increase the interest of people to attend the performances. This study examines the view of new students towards the Ngesti Pandawa wayang theatre. The results shows that young people are still interested in the wayang orang Ngesti Pandawa. They also have given various inputs on how to increase the audience number and keep the Wayang Orang well preserved
\end{abstract}

Keywords: Wayang Orang; Ngesti Pandawa; Finantial Technology; Internet Technology ; sosial media integration.

\section{Background}

Today's Indonesian society that tends to think to the west of the global has many challenges. One of them maintains and promotes aspects of indigenous culture of Indonesia. Culture can be expressed well in various ways such as art, linguistic or architectural aspects. Cultural heritage has an important value that must be promoted and preserved for future generations, because the destruction or destruction of a culture is an irreversible loss.

Culture is a source of wealth because it can be processed into creative arts tourism. Millions of tourists choose cultural tours such as monuments, museums, exhibitions, historic villages, ruins.

Attempts to protect and preserve wayang culture in line with efforts to realize low carbon development, as well as the preservation of wayang culture can be utilized also in environmental sustainability education and the availability of natural resources.

Wayang orang is one of a cultural heritages that until now still be preserved. Wayang enacts stories depicting struggles between good and evil. For centuriesold wayang stories have been performed by all levels in of society, and watched by millions of spectators. Wayang is considerd as a masterpiece, a literary work and / or cultural majesty [1]. Wayang has been recognised by UNESCO as Masterpiece of Oral and Intangible Heritage Humanity

In Indonesia there are several wayang orang groups, among the larger ones are the Wayang Orang Sriwedari (Solo), Wayang Orang Barata (Jakarta) and Wayang Ngesti Pandawa (Semarang). In the villages there are also many small amateur groups. Wayang orang Ngesti Pandawa was established in 1973 and settled permanently in the city of Semarang since 1949. It still performs regularly today. However, today the the performances are considered to take too much time and tend to be tedious. Most of the people who come towatch it are elderly people.

Bringing in famous artists, comedians, inviting organizations to perform together, and publishing books on Ngesti Pandowo are some of the efforts taken to improve the finances of the group as well as the individual players. Today, because the income received as a wayang orang actor is small they are forced to have other jobs as their main source of income.

Currently, Ngesti Pandawa finds it difficult to attract spectators. The number of people watching its performances are few, mostly residents of Semarang and its surroundings. How can Wayang Orang Ngesti Pandawa attract a wider audience, including those from abroad? Can Internet technology make Wayang Orang Ngesti Pandawa more well known and become a cultural center and a tourism destination?

* Corresponding author: maryono@pwk.undip.ac.id 


\section{Literature Review}

Cultural heritage is recognized as having historical, social, and anthropological values and is regarded as an enabler of sustainable development [4]. Therefore sustainable development should also put emphasize on the protection of cultural heritage. Maintaining cultural heritage through sustainable tourism will create jobs and promote local culture and products.

Young people, in this case university 'students, can be invited to be involved in the preservation of culture [5], this shows that cultural opportunities in tourism are still open.

Internet technology can facilitate the conservation of cultural heritage by enabling data management [6] and the combination of these technologies can overcome various cultural heritage issues.

Fintech (financial technology) is an innovation in the field of finance based on internet technology [3]. Utilizing Fintech can bring in a more practical and secure financial transaction process.Social media is very useful and important in building images, strengthening relationships, and networking between business and customer entrepreneurs, recommendations to make social media more visible and significant among business entrepreneurs[7]. Social media can be used by organizations as a marketing tool. Social media allows business organizations to communicate with customers at low cost and efficiency because they do not have to meet in person. So any kind of business can take advantage of social media for promotion. Social media such as Facebook, Twitter, Instagram which is widely used allows users to follow their favorite brand and comment or post questions related to relevant products or services.

Utilization of social media and the Internet becomes a very important requirement for small businesses (SMEs). SMEs should be competitive and keep innovating. Using social media strategically for marketing is considered to have a significant positive impact on small business entrepreneurs and indirectly on economic growth [8]. It is undeniable that the Internet is the backbone of internet based business [9]. The Internet is the most important globalization vehicle. E-commerce technology is helpful to small entrepreneurs and small businesses are dependent on it [10]. Businesses must have an attractive website designed to attract visitors and increase company popularity. Furthermore, by using internet technology all business processes become faster and easier.

\section{Methodology}

1. Website development: developing a website that is able to provide complete information about Ngesti Pandawa, Wikipedia, and cooperation with Tiket.com, provider of financial technology, to support online transactions.
2. Blog-based support websites, building a community that can contribute to the dissemination of information about Ngesti Pandawa.

3. Cooperation with tourism agencies and hotels to disseminate information.

4. Social media development.

a. Facebook, Twitter: create facebook account and spread information through facebook.

b. Instagram social media development: create Instagram and disseminate information

c. Development of youtube videos: create videos to disseminate information and visualization of the wayang orang Ngesti Pandawa

5. Development ChatBot Line: robot chat technology to help people obtain information about ngesti pandawa

6. Analyze the results of the application

7. Conclusion.

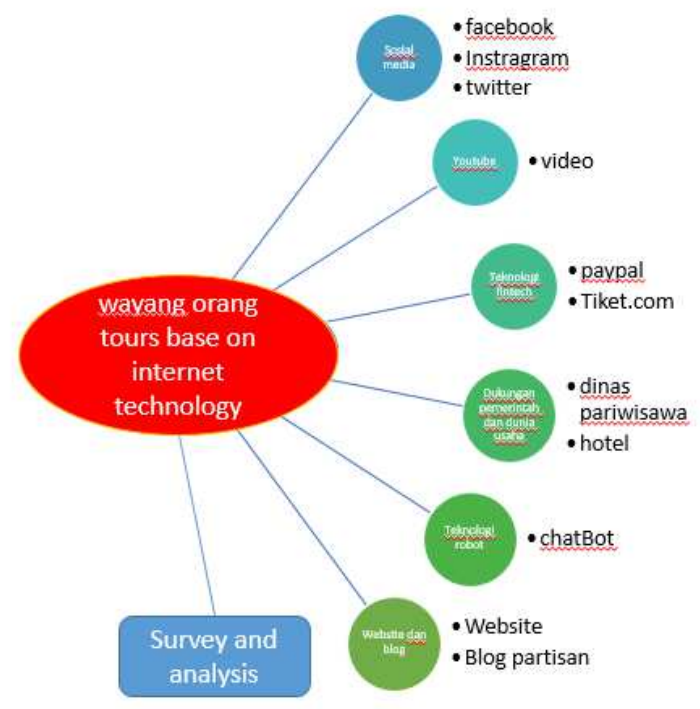

Fig. 1. Frame of mind integration of internet technology.

To make optimal use of the website (http://www.ngestipandawa.com/) as many information as possible on the activities of Ngesti Pandawa are constantly updated, such as performance times, title of plays, venue addresses, contacts, management, social media (facebook, twiter, Instagram). A tripadvisor link has also been added (https://www.tripadvisor.com) which also gives detailed information about Ngesti Pandawa.

Wikipedia

https://en.wikipedia.org/wiki/Ngesti_Pandawa is expected to assist in providing more details about Ngesti Pandawa's history and current activities.

Currently there are two fintechs that can be utilized and have been integrated with the website of Ngesti Pandawa. They are Tiket.com and Paypal.com.

Tiket.com is owned by PT. Global Ticket Network which has an international reach and offers online reservation and payment services. Booking airline 
tickets, hotels, trains, events and attractions can also be done through Tiket.com. Tiket.com has 14 payment methods at various banks in Indonesia.

Paypal is a non-physical payment alternative that is online to the world. It is now the largest company in online payment by working with companies around the world. Paypal serves as a payment processor for online vendors, auction sites and other commercial users. For international transactions Paypal.com uses Visa, Mastercard, Discover and Mastro. To be integrated with Fintech, Ngesti Pandawa must provide copies of ID, ministral decree, taxpayer ID number, company registration certificate, business permit, deed of establishment, domicile decree, bank report for the last three months, proof of premise lease / ownership, company seal/stamp and informative website. The permit process must always be communicated with the contact person of each fintech; and because it could not be uploaded online it had to be sent in hard copy form (paper) eg the MOUs between related business units.

The Fintech service has features for Web Integration, Mobile Applications, Link Payments, Invoicing Payments, which can be used for optimal marketing and online sales. Fintech's implementation on the website of Ngesti Pandowo is shown in the picture below. Utilizing API technology owned by fintech is done by using through a controlled website.

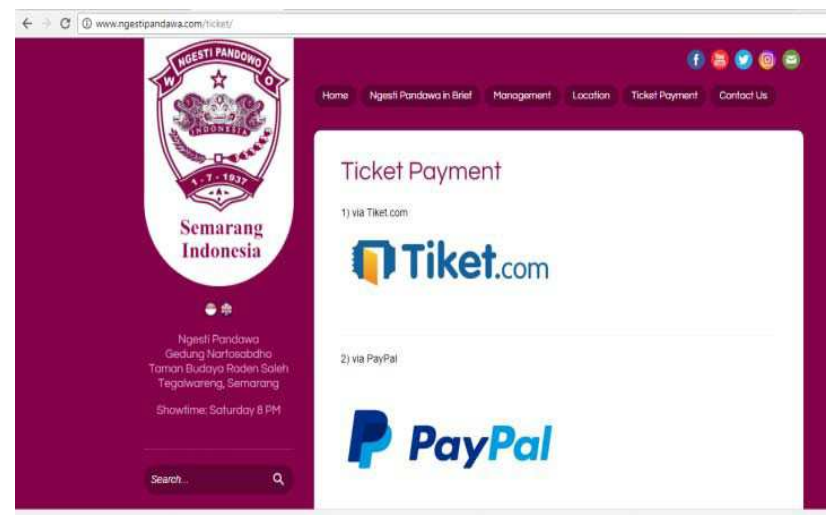

Fig. 2. The Fintech service

Cooperation with various parties (government and the tourism industry) in promoting wayang orang Ngesti Pandawa is important. The cooperation is with the Central Java Tourism Office and various hotels in Semarang to help spread the information as shown in the picture below.
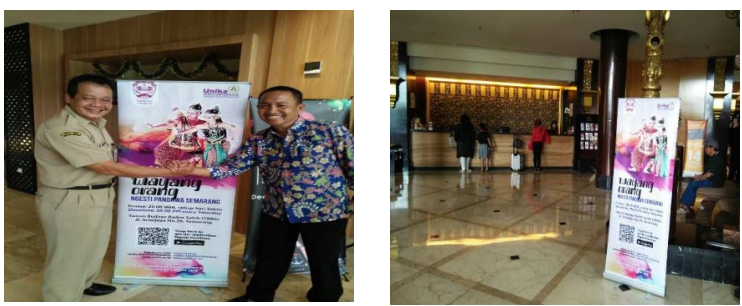
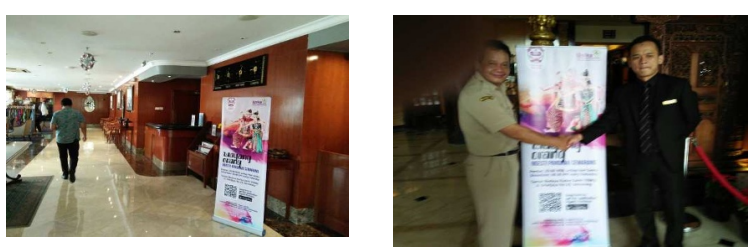

Fig. 3. The cooperation is with the Central Java Tourism Office and various hotels in Semarang

In cooperation with the Department of Youth, Sports and Tourism (Disporapar) of Central Java Province, Creative Economy Agency (BEKRAF), Ngesti Pandawa held a panel discussion on the future of wayang orang in Indonesia. This is part of an effort to preserve wayang orang. Efforts in the preservation of wayang can not be done alone by one party, but requires a close cooperation between actors, government, business, and academia.

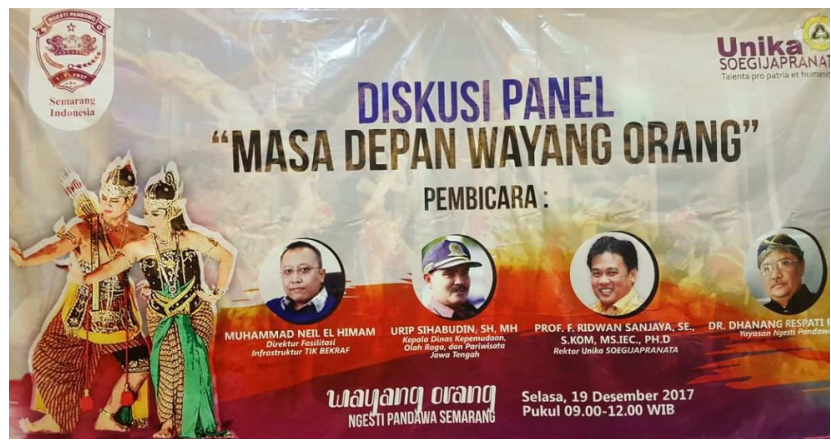

Fig. 4. In cooperation with the Department of Youth, Sports and Tourism of Central Java Province, Creative Economy Agency BEKRAF

Social media is an important part of the promotion efforts. Facebook, Instagram, and Twitter is used to disseminate information about the performance schedule and activities that has taken place. Instagram, which is popular amongst young people, is expected to bring wayang orang closer to them through the use of instastory. Tags and Hashtags function to tag friends or group photos in a single label to spread information to many people.Caption serves to provide a description of the uploaded photos. Integration to photo and video sharing social networks and other social networks like Facebook, Twitter makes it possible that every time a photo is shared, Instagram will automatically share it to: makin the connected social network.

Development of youtube makes it possible to publish videos on wayang orang performances.

Chatbot service is a new technology program to simulate conversations supported by artificial intelligence and rules. Chatbot works in providing specific responses according to the rules created. Chatbot is utilized to serve customers, conduct polls, and offers discounts. By using chatbot informations on Ngesti Pandawa can be seen quickly. 


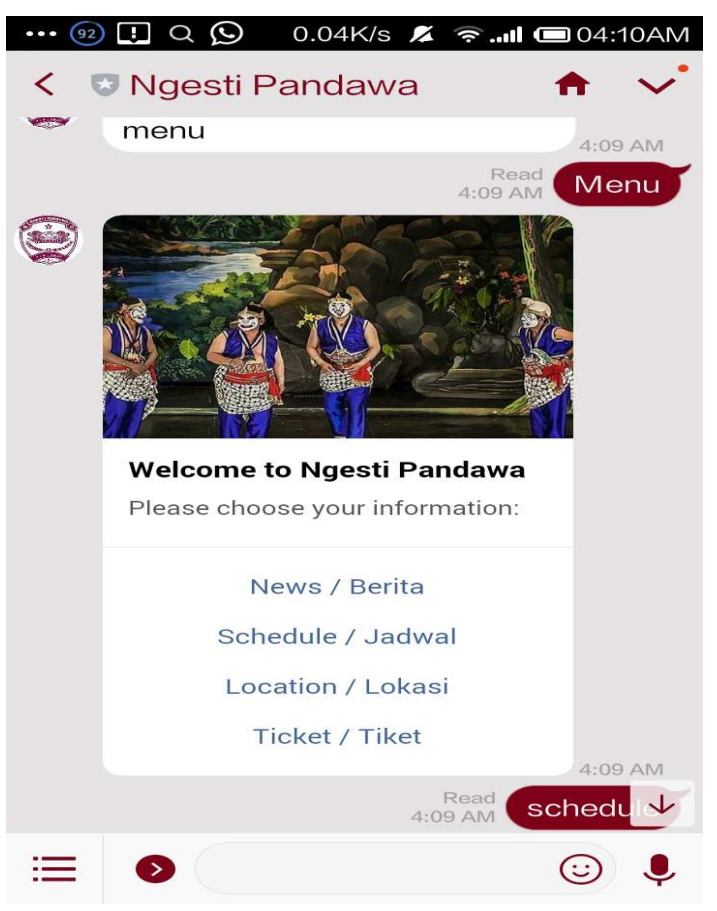

Fig. 5. Chatbot service

The survery was conducted involving 277 freshmen students of class 2017. The findings presented in the following table shows that young people do know about wayang orang; some have even see a wayang orang performance albeit only once Students often make online transactions, but only one student used online transactions to watch a wayang orang performance.

Table 1. Formatting sections, subsections and subsubsections

\begin{tabular}{|c|c|c|c|c|}
\hline No & Pertanyaan & Ya & Tidak & Total \\
\hline 1 & $\begin{array}{l}\text { Do you know the } \\
\text { culture of your } \\
\text { region? }\end{array}$ & $\begin{array}{c}256 \\
95.88 \%\end{array}$ & 11 & 267 \\
\hline 2 & $\begin{array}{l}\text { Do you know } \\
\text { wayang orang? }\end{array}$ & $\begin{array}{c}258 \\
94.51 \%\end{array}$ & 15 & 273 \\
\hline 3 & $\begin{array}{l}\text { Have you ever seen } \\
\text { a wayang orang } \\
\text { performance? }\end{array}$ & $\begin{array}{c}182 \\
69.73 \%\end{array}$ & 79 & 261 \\
\hline 4 & $\begin{array}{l}\text { Have you ever used } \\
\text { online transaction to } \\
\text { buy a ticket? }\end{array}$ & $\begin{array}{c}157 \\
58.36 \%\end{array}$ & 112 & 269 \\
\hline 5 & $\begin{array}{l}\text { Have you ever used } \\
\text { online transaction to } \\
\text { obtain a wayang } \\
\text { orang ticket? }\end{array}$ & $\begin{array}{c}1 \\
0.36 \%\end{array}$ & 276 & 277 \\
\hline 6 & $\begin{array}{l}\text { Do you the wayang } \\
\text { orang Ngesti } \\
\text { Pandawa Semaran? }\end{array}$ & $\begin{array}{c}88 \\
32.23 \%\end{array}$ & 185 & 273 \\
\hline 7 & $\begin{array}{l}\text { Can wayang orang } \\
\text { still be promoted as } \\
\text { a tourist attraction? }\end{array}$ & $\begin{array}{c}205 \\
80.39 \%\end{array}$ & 50 & 255 \\
\hline
\end{tabular}

\begin{tabular}{|l|l|c|c|c|}
\hline 8 & $\begin{array}{l}\text { Have you ever seen } \\
\text { ads/promotion on } \\
\text { wayang orang in the } \\
\text { social media? }\end{array}$ & $\begin{array}{l}15 \\
5.45 \%\end{array}$ & 260 & 275 \\
\hline
\end{tabular}

Only $32 \%$ of the student respondents know about Ngesti Pandawa. Therefore, there is still a need for more vigorous campaign to make wayang orang better known amongst young people.

Eighty percent of the students view that wayang orang Ngesti Pandawa is still worth to be promoted as a form of cultural tourism. Promotion through social media has still must be intensified because only $5.45 \%$ of students has ever see the promotion of wayang orang using social media.

Although it still might take a long time to introduce and promote wayang orang Ngesti Pandawa, there are already online transactions through Tiket.Com. There have been 8 people who used Tiket.com, one from abroad $\mathrm{s}$ and 7 people from outside Central Java. This shows that promotion using information technology has begun to show results.

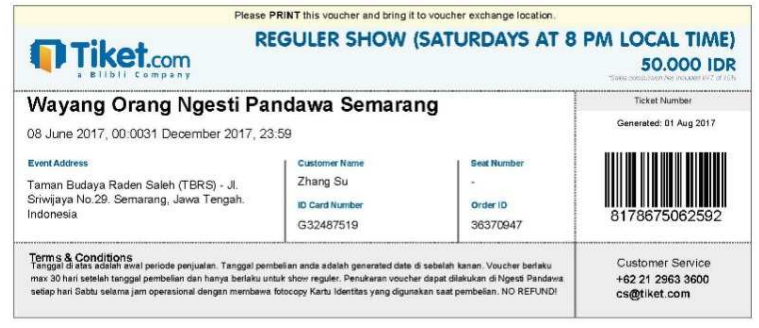

Fig. 6. proof of transaction

\section{Conclusion:}

The Internet technology can be a useful tool for small businesses. The level of usefulness depends on a manager who is able to use a technology that is actually easy to use. The Internet can be a marketing tool, or a new mode of transaction, or in creating setting where small businesses can meet new customers. Internet technology can be utilized to increase the popularity of Ngesti Pandawa, shown by the fact that transactions using Fintech technology has already started.

\section{Acknowledgment}

This research is funded by the Directorate of Higher Education through the University Superior Research scheme in 2018. The title of the reserach is "Model and Implementation of Wayang Orang Creative Industry based on Information Technology Support. 


\section{References}

1 G. Cantatore and S. Quappe, "What is Cultural Awareness , anyway? How do I build it?," Www.Culturiosity.Com, pp. 1-3, 2005.

2 B. Nurgiyantoro, "Wayang dan pengembangan karakter bangsa," Wayang Dan Pengemb. Karakter Bangsa, no. 1, pp. 1-17, 2011.

3 A. Dwiyoga, R. Sanjaya, T. Rahardjo, and R. Djati, "Review on the Application of Financial Technology for the Wayang Orang Ngesti Pandowo Cultural Creative Industry," Proc. 2017 4th Int. Conf. Inf. Tech., Comput. Electr. Eng., pp. 221-225, 2017.

4 W. Xiao, J. Mills, G. Guidi, P. RodríguezGonzálvez, S. Gonizzi Barsanti, and D. González-Aguilera, "Geoinformatics for the conservation and promotion of cultural heritage in support of the UN Sustainable Development Goals," ISPRS J. Photogramm. Remote Sens., 2018.

5 A. D. Widiantoro and R. Sanjaya, "Increase Student Awareness of People's Cultural Heritage Using Internet Technology," no.
March, 2018.

A. Perles et al., "An energy-efficient internet of things (IoT) architecture for preventive conservation of cultural heritage," Futur. Gener. Comput. Syst., vol. 81, pp. 566-581, 2018. R. Kahar, F. Yamimi, G. Bunari, and H. Habil, "Trusting the Social Media in Small Business," Procedia - Soc. Behav. Sci., vol. 66, pp. 564570, 2012.

8 S. Hassan, S. Z. A. Nadzim, and N. Shiratuddin, "Strategic Use of Social Media for Small Business Based on the AIDA Model," Procedia - Soc. Behav. Sci., vol. 172, pp. 262-269, 2015.

9 S. Feizollahi, A. Shirmohammadi, Z. S. Kahreh, and M. S. Kaherh, "Investigation the Effect of Internet Technology on Performance of Services Organizations with e-commerce Orientations," Procedia - Soc. Behav. Sci., vol. 109, pp. 605609, 2014.

10 Barhatov V, Campa A, and Pletnev D, "The Impact of Internet-Technologies Development on Small Business Success in Russia," Procedia - Soc. Behav. Sci., vol. 238, pp. 552-561, 2018. 